\title{
ATP consumption in molecular signaling of CA1 Hippocampus neurons
}

\author{
Nikon Rasumov ${ }^{*}$, Erik De Schutter \\ From 24th Annual Computational Neuroscience Meeting: CNS*2015 \\ Prague, Czech Republic. 18-23 July 2015
}

The human brain consumes $10^{6}$ times less energy than the currently fastest super computer [1], while maintaining a comparable performance in many demanding tasks [2]. This energetic efficiency has been suggested to result from primitive computations on a molecular level [3]. However, while the importance of ion channels on energy efficiency has been the primary focus of research $[4,5]$, most computations occur at the molecular level prior to the amplification step and prior to the information transmission through neurons. We calculate the amount of energy consumed by such computations and compare their structural and functional properties. As a starting point, we chose 2000 reactions in the signaling pathways of CA1 hippocampal neurons [6]. As not every reaction consumes either one or zero ATPs, we undergo a wide literature search to identify the exact energy consumption of over 60 million of possible feedback loops. We find that the number of ATPs consumed is related with size of positive feedback loop. Hence, this study provides the first systematic and detailed attempt to investigate the energy consumption of information-storing primitive computations and points towards energy efficient motifs for synthetic biology.

\section{Acknowledgements}

This work was supported by funding from the De Schutter Unit Okinawa Institute of Science and Technology Graduate University.

\section{Published: 18 December 2015}

\section{References}

1. Niven JE, Laughlin SB: Energy limitation as a selective pressure on the evolution of sensory systems. Journal of Experimental Biology 2008, 211(11):1792-1804.

2. Ferrucci DA: Introduction to "This is Watson". Ibm Journal of Research and Development 2012, 56(3-4):15.

\footnotetext{
* Correspondence: nikon@oist.jp
}

Okinawa Institute of Science and Technology Graduate University, Onna, Okinawa 904 0495, Japan

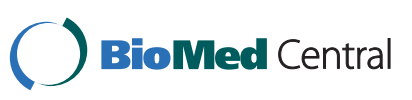

(c) 2015 Rasumov and De Schutter This is an Open Access article distributed under the terms of the Creative Commons Attribution License (http://creativecommons.org/licenses/by/4.0), which permits unrestricted use, distribution, and reproduction in any medium, provided the original work is properly cited. The Creative Commons Public Domain Dedication waiver (http://creativecommons.org/ publicdomain/zero/1.0/) applies to the data made available in this article, unless otherwise stated.
3. Mead C: Neuromorphic Electronic Systems. Proceedings of the IEEE 1990, 78(10):1629-1636.

4. Sengupta B, Stemmler M, Laughlin SB, Niven JE: Action Potential Energy Efficiency Varies Among Neuron Types in Vertebrates and Invertebrates. PLoS Computational Biology 2010, 6(7).

5. Alle H, Roth A, Geiger JRP: Energy-Efficient Action Potentials in Hippocampal Mossy Fibers. Science 2009, 325(5946):1405-1408.

6. Ma'ayan A, Cecchi GA, Wagner J, Rao AR, lyengar R, Stolovitzky G: Ordered cyclic motifs contribute to dynamic stability in biological and engineered networks. Proc Natl Acad Sci U S A 2008, 105(49):19235-19240.

doi:10.1186/1471-2202-16-S1-P56

Cite this article as: Rasumov and De Schutter: ATP consumption in molecular signaling of CA1 Hippocampus neurons. BMC Neuroscience 2015 16(Suppl 1):P56.
Submit your next manuscript to BioMed Central and take full advantage of:

- Convenient online submission

- Thorough peer review

- Immediate publication on acceptance

- Inclusion in PubMed, CAS, Scopus and Google Scholar

- Research which is freely available for redistribution Submit your manuscript at
www.biomedcentral.com/submit C BioMed Central
- No space constraints or color figure charges 